r ScIDioc

\section{Comparison of Linear Measurements of Tongue and Lower Airway in Skeletal Class Ii with Various Growth Pattern}

Research Article

H. Sruthi ${ }^{1}$, Navaneethan. $\mathrm{R}^{2 *}$, Sri Rengalakshmi ${ }^{3}$

${ }^{1,2}$ Department of Orthodontics and Dentofacial Orthopaedics, Saveetha Dental College and Hospital, Saveetha Institute of Medical and Technical Sciences (SIMATS), Saveetha University, Chennai, India.

${ }^{3}$ Senior Lecturer, Department of Orthodontics and Dentofacial Orthopaedics, Saveetha Dental College and Hospital, Saveetha Institute of Medical and Technical Sciences (SIMATS), Saveetha University, Chennai, India.

\title{
Abstract
}

The volume of functional spaces such as Oral, Nasal and Pharyngeal spaces and the patency of the Orofacial area is maintained due to the postural activity of the Orofacial musculature and soft tissue wall formed by lips, cheeks, floor of the mouth, tongue, soft palate. According to Functional matrix theory form and function are interrelated. Tongue and Airway also plays a major role in Normal growth and development of craniofacial structures. Their dimensions have been shown to alter in various studies in Skeletal class II patients. The aim of this present research is to compare and evaluate the linear measurement of tongue and lower airway in skeletal Class II patients with various skeletal growth patterns. 60 Lateral Cephalograms which matched the inclusion criteria were selected from the case records of patients who reported for orthodontic treatment in a university hospital. They were grouped equally among the three growth patterns. All linear measurements of tongue and lower oropharyngeal airway were measured. The result shows that there is no significant difference in the linear measurement of width of the lower pharyngeal airway ( $\mathrm{p}-0.49)$ and Tongue length in Skeletal class two patients with various growth patterns (p-0.88).

Keywords: Tongue; Lower Oropharyngeal Airway; Growth Pattern; Skeletal Class Ii.

\section{Introduction}

The Orofacial region is responsible for several vital functions such as deglutition, respiration, and gustation. The volume of functional spaces such as Oral, Nasal and Pharyngeal spaces and the patency of the Orofacial area is maintained due to the postural activity of the Orofacial musculature and soft tissue wall formed by lips, cheeks, floor of the mouth, tongue, soft palate This Interaction interdependence between the Form and function has been stated by the Functional matrix theory (Melvin L. Moss, 1997a, 1997b, 1997c; M. L. Moss, 1997) and is widely accepted in orthodontics. Has been shown to be interdependent. Tongue is the largest organ in the oral cavity. Any abnormalities in its growth, position and function has been shown to be associated with Malocclusion in several studies $[35,13,38]$. Similarly Airway also plays a major role in Normal growth and development of craniofacial structures. Mouth breathing and Obstructive sleep apnea OSA has been found to be associated with Narrow pharyngeal airway. A reduction of $25 \%$ in oropharyngeal and hypopharyngeal airway has been reported in OSA patients [6].

A skeletal class two malocclusion can be caused by protrusive maxilla, retrusive mandible, or a combination of both [30]. Balter's philosophy states that, Class II malocclusion can occur as a consequence of backward position of a tongue. Pharyngeal airway space has been shown to be largest in mandibular prognathism and least in mandibular retrognathism [29]. There are several studies which have shown that Pharyngeal airway dimensions decreases in Class II patients [23, 19]. Thus, Any changes in spatial relationship in the tongue, airway have wide functional importance and reciprocal consequences. This necessitates assessment of tongue and airway as a routine in orthodontic diagnosis and treatment planning as a functional, positional and structural assessment of dentofacial pattern. Previously our team has a rich

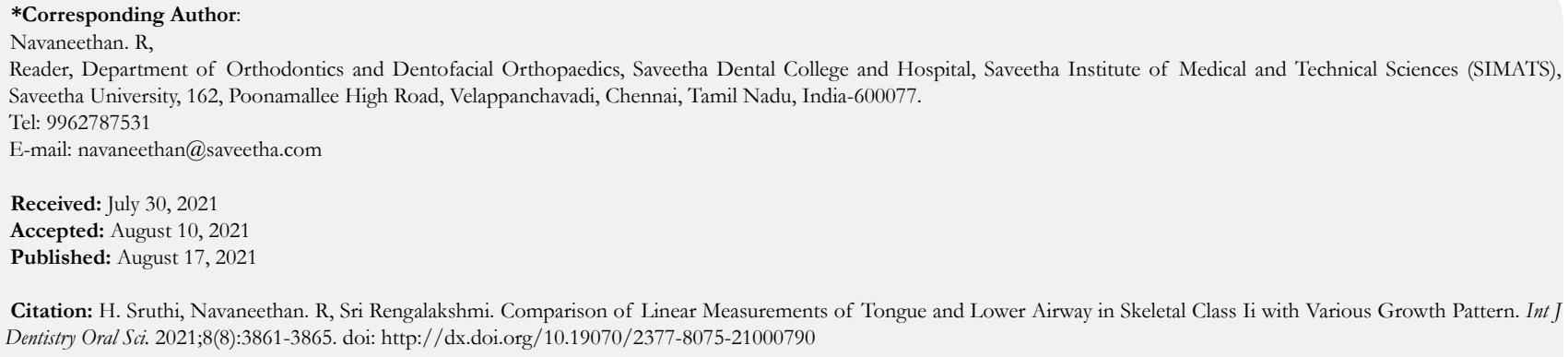

Copyright: Navaneethan. $\mathbf{R}^{\circ}$ 2021. This is an open-access article distributed under the terms of the Creative Commons Attribution License, which permits unrestricted use, distribution and reproduction in any medium, provided the original author and source are credited. 
experience in working on various research projects across multiple disciplines $[40,15,53,33,31,47,28,14,5,37,48,36,2,55$, 1]. Now the growing trend in this area motivated us to pursue this project.

The aim of this present research is to compare and evaluate the linear measurement of tongue and lower airway in skeletal Class II patient patients between various growth patterns of the mandible in the vertical dimension.

\section{Materials And Methods}

Our sample size was calculated to be 60 using $G$ power software version 3.1 [4]. Ethical committee clearance approval was obtained from the Institutional review board. This retrospective study was carried out in several stages. The patients were selected from the patients who had reported to the Department of Orthodontics at Saveetha dental college, Chennai for orthodontic treatment between March 2020- March 2019.

\section{Inclusion criteria:}

1. All permanent teeth were present (3rd molars were excluded).

2. ANB angle $>4$ degree.(Skeletal class two pattern)

3. All patients had either horizontal, vertical growth pattern or Average growth pattern.

4. Clear lateral cephalograms with adequate contrast.

\section{Exclusion criteria:}

1. Patients with missing teeth or impacted teeth.

2. History of orthodontic treatment.

3. Cleft lip \& palate.

4. Craniofacial anomalies or syndromes.

5. TMJ disorders.

6. Trauma to face.

Mandibular Plane angle formed by Sella-Nasion \& GonionGnathion planes were used to analyse growth pattern of the mandible from the Lateral Cephalograms and segregate them into various growth patterns namely Average growth pattern where the angle is between 30-320, Horizontal growth where the angle is pattern $<300$ and Vertical growth pattern where the angle is $>340$. All Cephalometric analysis were made using FACAD software. 60 Lateral Cephalogram were sorted into 3 groups with 20 in each growth pattern.

Linear dimensions of Tongue and Lower oropharyngeal airway were measured in all 60 lateral cephalograms. Tongue length -Linear distance between the deepest point on epiglottis and center of the tip of the tongue and the width of the lower oropharyngeal airway was measured as the Distance between po89 \int on the posterior pharyngeal wall and point on the tongue along the mandibular lower border were measured (Figure 1).

Previously our team had conducted numerous clinical trials (Kamisetty et al., 2015 [18]; Krishnan, Pandian and Kumar S, 2015 [21]; Viswanath et al., 2015 [54]; Sivamurthy and Sundari, 2016 [49]; Felicita, 2017b [10]; Samantha et al., 2017 [45]; Vikram et al., 2017 [53]) and lab animal studies (Ramesh Kumar et al., 2011 [42]; Felicita, Chandrasekar and Shanthasundari, 2012 [12]; Rubika, Sumathi Felicita and Sivambiga, 2015 [44]; Felicita, 2017a [9];
Pandian, Krishnan and Kumar, 2018 [32]) and in-vitro (Dinesh et al., 2013 [7]; Jain, Kumar and Manjula, 2014 [17]; Felicita, 2018 [11]) studies over the past 5 years. The idea for this study stemmed from the current interest regarding the airway in class II patients. Hence this study was conducted to evaluate the airway and tongue in Class II individuals.

\section{Statistical Analysis}

For all growth patterns 2 different parameters i.e. Length of the tongue and Width of the lower oropharyngeal airway were measured separately for 60 lateral cephalogram samples. To know if there was any association between the three growth patterns i.e. Horizontal, vertical and average facial growth patterns and Linear dimension of tongue and lower oropharyngeal airway one way -ANOVA was performed with 95\% confidence level and 1 degree of freedom to cross tabulate data.

\section{Results \& Discussion}

Figure 2 shows Mean value of Length of the tongue and Width of the lower oropharyngeal airway measured in various growth patterns. The legends in the bar graph (red) shows the mean Length of the tongue in horizontal growth pattern is $80.7 \mathrm{~mm}$, in vertical growth pattern is $80.1 \mathrm{~mm}$ and in average growth pattern is $81 \mathrm{~mm}$.The legends in (grey) bar graph shows the mean width of the lower oropharyngeal airway in horizontal growth pattern is $13.3 \mathrm{~mm}$, in vertical growth pattern is $13.3 \mathrm{~mm}$ and in average growth pattern is $12.8 \mathrm{~mm}$.

One-way ANOVA comparing Width of the lower oropharynx among various growth patterns showed no significant difference between the groups (p-0.49) (Refer Table 1). One-way ANOVA comparing Length of the tongue among various growth patterns showed no significant difference between the groups ( $\mathrm{p}-0.88) \mathrm{Re}$ fer Table 1.

In the present study linear measurement - Length of the tongue and width of the lower pharyngeal airway showed no significant difference in skeletal class two patients with various growth patterns. In a previous study by Chauhan et al. [4] where they compared the pharyngeal airway dimensions between Class II and Class I patients showed that the mean linear and angular measurement were lower in skeletal class II patients but were not significantly different between the Groups. Similarly in the present study the lower airway dimension showed that the mean values are reduced in average growth pattern and almost similar in horizontal and vertical growth pattern. However there was no statistically significant difference between the groups. In a study by Kirjavainen et al. [20]. It was shown that Class II patients have narrow oropharyngeal and hypopharyngeal space. In a study by Sukniyom et al. [51]. They assessed the various treatment modality effects on class II patient airways and concluded that Non-extraction treatment with Class II traction showed significant increase in the pharyngeal airway. In a cephalometric evaluation of pharyngeal airway by muto et al. [29] Mandibular retrognathism is the major risk factor for narrowing of pharyngeal airway.

Chauhan et al. [4] showed that mean tongue length decreased in Class II patients than class I but were not statistically significant between the groups but showed inferior positioning of the 
Figure 1:Depicts the various Linear measurements, Length of the tongue-Linear distance between the deepest point on epiglottis and center of the tip of the tongue and Width of the lower oropharyngeal airway -Distance between point on the posterior pharyngeal wall and point on the tongue along the mandibular lower border.

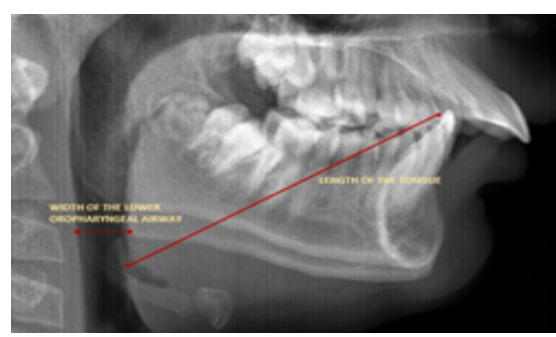

Figure 2: Bar graph depicting the mean values of linear dimensions measured-Length of the tongue (red) and Width of the lower oropharyngeal airway (grey) measured in various growth patterns. $X$ axis represents the various growth patterns and the $Y$ axis the linear measurements. The legends in the bar graph (red) shows the mean Length of the tongue in horizontal growth pattern is $80.7 \mathrm{~mm}$, in vertical growth pattern is $80.1 \mathrm{~mm}$ and in average growth pattern is $81 \mathrm{~mm}$. The legends in (grey) bar graph shows the mean width of the lower oropharyngeal airway in horizontal growth pattern is $13.3 \mathrm{~mm}$, in vertical growth pattern is $13.3 \mathrm{~mm}$ and in average growth pattern is $12.8 \mathrm{~mm}$.It could be inferred from the graph that both the width of the lower oropharyngeal airway and the length of the tongue did not show much variation among various growth pattern.

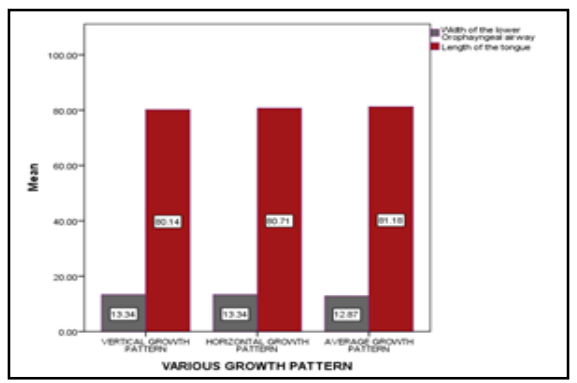

Table 1: Table depicting the association between the various growth patterns and the linear measurement -Length of the tongue, width of lower oropharyngeal airway. One-way ANOVA comparing length of the tongue among various growth patterns showed no significant difference between the groups (p-0.498). One-way ANOVA comparing width of the lower oropharyngeal airway dimension among Various growth patterns showed no significant difference between the groups $(\mathrm{p}-0.887) .(>0.05)$, hence statistically not significant.

\begin{tabular}{|c|c|c|c|c|c|c|}
\hline \multicolumn{7}{|c|}{ ANOVA } \\
\hline & & $\begin{array}{l}\text { Sum of } \\
\text { Squares }\end{array}$ & df & $\begin{array}{l}\text { Mean } \\
\text { Square }\end{array}$ & $\mathrm{F}$ & Sig. \\
\hline \multirow{3}{*}{$\begin{array}{l}\text { Width of the Lower } \\
\text { Oropharyngeal airway }\end{array}$} & Between Groups & 2.466 & 2 & 1.233 & 0.707 & 0.498 \\
\hline & Within Groups & 81.914 & 47 & 1.743 & & \\
\hline & Total & 84.38 & 49 & & & \\
\hline \multirow[t]{3}{*}{ Length of the tongue } & Between Groups & 8.899 & 2 & 4.45 & 0.12 & 0.887 \\
\hline & Within Groups & 1739.293 & 47 & 37.006 & & \\
\hline & Total & 1748.193 & 49 & & & \\
\hline
\end{tabular}

tongue. Similarly in the present study mean tongue lengths decreased in Vertical growth pattern but were not statistically significant. In a study by Ihan et al(Ihan Hren and Barbič, 2016) [16] using three dimensional Ultrasound showed that tongue volume increases in skeletal class III patients. In a study by Yoo et al. [56] concluded that tongue volume is dependent on the horizontal and vertical location of the Chin and symphysis and does not increase only because of mandibular prognathism.

The limitations of this study include Retrospective study design, Two Dimensional Imaging technique, smaller sample size and other parameters are not assessed. Future scope involves a multicentric study design with other parameters assessed simultaneously in three dimensions would provide better results.

Our institution is passionate about high quality evidence based research and has excelled in various fields ( (Pc, Marimuthu and Devadoss, 2018 [34]; Priyadharsini et al., 2018 [36]; Ramesh et al.,
2018 [41]; Ezhilarasan, Apoorva and Ashok Vardhan, 2019 [8]; Ramadurai et al., 2019 [39]; Sridharan et al., 2019 [50]; Vijayashree Priyadharsini, 2019 [52]; Chandrasekar et al., 2020 [3]; Mathew et al., 2020 [2]; R et al., 2020 [43]; Samuel, 2021 [46]). We hope this study adds to this rich legacy.

\section{Conclusion}

Within the limitation of the study it was concluded that the growth pattern does not alter the linear measurement of width Lower pharyngeal airway and tongue length in skeletal class II skeletal pattern.

\section{References}

[1]. Abitha T, Santhanam A. Correlation between bizygomatic and maxillary central incisor width for gender identification. Brazilian Dental Science. 2019 Oct 31;22(4):458-66. 
[2]. Azeem RA, Sureshbabu NM. Clinical performance of direct versus indirect composite restorations in posterior teeth: A systematic review. J Conserv Dent. 2018 Jan-Feb;21(1):2-9. Pubmed PMID: 29628639

[3]. Chandrasekar R, Chandrasekhar S, Sundari KKS, Ravi P. Development and validation of a formula for objective assessment of cervical vertebral bone age. Prog Orthod. 2020 Oct 12;21(1):38. Pubmed PMID: 33043408.

[4]. Chauhan A, Autar R, Pradhan KL, Yadav V. Comparison of pharyngeal airway dimension, tongue and hyoid bone position based on ANB angle. Natl J Maxillofac Surg. 2015 Jan-Jun;6(1):42-51. Pubmed PMID: 26668452.

[5]. Chen F, Tang Y, Sun Y, Veeraraghavan VP, Mohan SK, Cui C. 6-shogaol, a active constiuents of ginger prevents UVB radiation mediated inflammation and oxidative stress through modulating $\mathrm{NrF} 2$ signaling in human epidermal keratinocytes (HaCaT cells). J Photochem Photobiol B. 2019 Aug;197:111518. Pubmed PMID: 31202076.

[6]. deBerry-Borowiecki B, Kukwa A, Blanks RH. Cephalometric analysis for diagnosis and treatment of obstructive sleep apnea. Laryngoscope. 1988 Feb;98(2):226-34. Pubmed PMID: 3339937.

[7]. Dinesh SP, Arun AV, Sundari KK, Samantha C, Ambika K. An indigenously designed apparatus for measuring orthodontic force. J Clin Diagn Res. 2013 Nov;7(11):2623-6. Pubmed PMID: 24392423.

[8]. Ezhilarasan D, Apoorva VS, Ashok Vardhan N. Syzygium cumini extract induced reactive oxygen species-mediated apoptosis in human oral squamous carcinoma cells. J Oral Pathol Med. 2019 Feb;48(2):115-121. Pubmed PMID: 30451321

[9]. Felicita AS. Orthodontic management of a dilacerated central incisor and partially impacted canine with unilateral extraction - A case report. Saudi Dent J. 2017 Oct;29(4):185-193. Pubmed PMID: 29033530.

[10]. Felicita AS. Quantification of intrusive/retraction force and moment generated during en-masse retraction of maxillary anterior teeth using mini-implants: A conceptual approach. Dental Press J Orthod. 2017 SepOct;22(5):47-55. Pubmed PMID: 29160344.

[11]. Felicita AS. Orthodontic extrusion of Ellis Class VIII fracture of maxillary lateral incisor - The sling shot method. Saudi Dent J. 2018 Jul;30(3):265269. Pubmed PMID: 29942113.

[12]. Felicita AS, Chandrasekar S, Shanthasundari KK. Determination of craniofacial relation among the subethnic Indian population: a modified approach - (Sagittal relation). Indian J Dent Res. 2012 May-Jun;23(3):305-12. Pubmed PMID: 23059564.

[13]. Fishman LS. Postural and dimensional changes in the tongue from rest position to occlusion. Angle Orthod. 1969 Apr;39(2):109-13. Pubmed PMID: 5252047.

[14]. Govindaraju L, Neelakantan P, Gutmann JL. Effect of root canal irrigating solutions on the compressive strength of tricalcium silicate cements. Clin Oral Investig. 2017 Mar;21(2):567-571. doi: 10.1007/s00784-016-1922-0. Epub 2016 Jul 28. PMID: 27469101

[15]. Gupta P, Ariga P, Deogade SC. Effect of Monopoly-coating Agent on the Surface Roughness of a Tissue Conditioner Subjected to Cleansing and Disinfection: A Contact Profilometric In vitro Study. Contemp Clin Dent. 2018 Jun;9(Suppl 1):S122-S126. Pubmed PMID: 29962776.

[16]. Ihan Hren N, Barbič U. Tongue volume in adults with skeletal Class III dentofacial deformities. Head Face Med. 2016 Mar 22;12:12. Pubmed PMID: 27004947.

[17]. Jain RK, Kumar SP, Manjula WS. Comparison of intrusion effects on maxillary incisors among mini implant anchorage, j-hook headgear and utility arch. J Clin Diagn Res. 2014 Jul;8(7):ZC21-4. Pubmed PMID: 25177631.

[18]. Kamisetty SK, Verma JK, Arun, Sundari S, Chandrasekhar S, Kumar A. SBS vs Inhouse Recycling Methods-An Invitro Evaluation. J Clin Diagn Res. 2015 Sep;9(9):ZC04-8. Pubmed PMID: 26501002.

[19]. Kerr WJ. The nasopharynx, face height, and overbite. Angle Orthod. 1985 Jan;55(1):31-6. doi: 10.1043/0003-3219(1985)055<0031:TNFHAO>2.0. CO;2. PMID: 3856405.

[20]. Kirjavainen M, Kirjavainen T. Upper airway dimensions in Class II malocclusion. Effects of headgear treatment. Angle Orthod. 2007 Nov;77(6):104653. Pubmed PMID: 18004913.

[21]. Krishnan S, Pandian S, Kumar S A. Effect of bisphosphonates on orthodontic tooth movement-an update. J Clin Diagn Res. 2015 Apr;9(4):ZE01-5. Pubmed PMID: 26023659.

[22]. Mathew MG, Samuel SR, Soni AJ, Roopa KB. Evaluation of adhesion of Streptococcus mutans, plaque accumulation on zirconia and stainless steel crowns, and surrounding gingival inflammation in primary molars: randomized controlled trial. Clin Oral Investig. 2020 Sep;24(9):3275-3280. doi: 10.1007/s00784-020-03204-9. Epub 2020 Jan 18. PMID: 31955271.

[23]. Mergen DC, Jacobs RM. The size of nasopharynx associated with normal occlusion and Class II malocclusion. Angle Orthod. 1970 Oct;40(4):342-6. Pubmed PMID: 5272410.

[24]. Moss ML. The functional matrix hypothesis revisited. 1 . The role of mechanotransduction. Am J Orthod Dentofacial Orthop. 1997 Jul;112(1):8-11. doi: 10.1016/s0889-5406(97)70267-1. PMID: 9228835.

[25]. Moss ML. The functional matrix hypothesis revisited. 2. The role of an osseous connected cellular network. Am J Orthod Dentofacial Orthop. 1997 Aug;112(2):221-6. Pubmed PMID: 9267235.

[26]. Moss ML. The functional matrix hypothesis revisited. 3. The genomic thesis. Am J Orthod Dentofacial Orthop. 1997 Sep;112(3):338-42. Pubmed PMID: 9294365.

[27]. Moss ML. The functional matrix hypothesis revisited. 4. The epigenetic antithesis and the resolving synthesis. Am J Orthod Dentofacial Orthop. 1997 Oct;112(4):410-7. Pubmed PMID: 9345153.

[28]. Muthukrishnan A, Warnakulasuriya S. Oral health consequences of smokeless tobacco use. Indian J Med Res. 2018 Jul;148(1):35-40. Pubmed PMID: 30264752.

[29]. Muto T, Yamazaki A, Takeda S. A cephalometric evaluation of the pharyngeal airway space in patients with mandibular retrognathia and prognathia, and normal subjects. Int J Oral Maxillofac Surg. 2008 Mar;37(3):228-31. Pubmed PMID: 18296029.

[30]. Pachori Y, Navlani M, Gaur T, Bhatnagar S. Treatment of skeletal class II division 1 malocclusion with mandibular deficiency using myofunctional appliances in growing individuals. J Indian Soc Pedod Prev Dent. 2012 JanMar:30(1):56-65. Pubmed PMID: 22565519

[31]. Palati S, Ramani P, Shrelin HJ, Sukumaran G, Ramasubramanian A, Don KR, Jayaraj G, Santhanam A. Knowledge, Attitude and practice survey on the perspective of oral lesions and dental health in geriatric patients residing in old age homes. Indian J Dent Res. 2020 Jan-Feb;31(1):22-25. Pubmed PMID: 32246676

[32]. Pandian KS, Krishnan S, Kumar SA. Angular photogrammetric analysis of the soft-tissue facial profile of Indian adults. Indian J Dent Res. $2018 \mathrm{Mar}-$ Apr;29(2):137-143. Pubmed PMID: 29652003

[33]. Paramasivam A, Vijayashree Priyadharsini J, Raghunandhakumar S. N6 adenosine methylation (m6A): a promising new molecular target in hypertension and cardiovascular diseases. Hypertens Res. 2020 Feb;43(2):153154. Pubmed PMID: 31578458

[34]. J PC, Marimuthu T, C K, Devadoss P, Kumar SM. Prevalence and measurement of anterior loop of the mandibular canal using CBCT: A cross sectional study. Clin Implant Dent Relat Res. 2018 Aug;20(4):531-534. Pubmed PMID: 29624863

[35]. Peat JH. A cephalometric study of tongue position. Am J Orthod. 1968 May;54(5):339-51. Pubmed PMID: 5238997.

[36]. Vijayashree Priyadharsini J, Smiline Girija AS, Paramasivam A. In silico analysis of virulence genes in an emerging dental pathogen A. baumannii and related species. Arch Oral Biol. 2018 Oct;94:93-98. Pubmed PMID: 30015217.

[37]. Priyanka S, Kaarthikeyan G, Nadathur JD, Mohanraj A, Kavarthapu A. Detection of cytomegalovirus, Epstein-Barr virus, and Torque Teno virus in subgingival and atheromatous plaques of cardiac patients with chronic periodontitis. J Indian Soc Periodontol. 2017 Nov-Dec;21(6):456-460. Pubmed PMID: 29551863.

[38]. Rakosi T. An atlas and manual of cephalometric radiography. 1982.

[39]. Ramadurai N, Gurunathan D, Samuel AV, Subramanian E, Rodrigues SJL. Effectiveness of $2 \%$ Articaine as an anesthetic agent in children: randomized controlled trial. Clin Oral Investig. 2019 Sep;23(9):3543-3550. Pubmed PMID: 30552590

[40]. Ramamurthy JA, Mg V. Comparison of effect of Hiora mouthwash versus Chlorhexidine mouthwash in gingivitis patients: A clinical trial. Asian J Pharm Clin Res. 2018 Jul 7;11(7):84-8.

[41]. Ramesh A, Varghese S, Jayakumar ND, Malaiappan S. Comparative estimation of sulfiredoxin levels between chronic periodontitis and healthy patients - A case-control study. J Periodontol. 2018 Oct;89(10):1241-1248. Pubmed PMID: 30044495.

[42]. Ramesh Kumar KR, Shanta Sundari KK, Venkatesan A, Chandrasekar S. Depth of resin penetration into enamel with 3 types of enamel conditioning methods: a confocal microscopic study. Am J Orthod Dentofacial Orthop. 2011 Oct;140(4):479-85. Pubmed PMID: 21967934

[43]. R H, Ramani P, Ramanathan A, R JM, S G, Ramasubramanian A, K M. CYP2 C9 polymorphism among patients with oral squamous cell carcinoma and its role in altering the metabolism of benzo[a]pyrene. Oral Surg Oral Med Oral Pathol Oral Radiol. 2020 Sep;130(3):306-312. Pubmed PMID 32773350 .

[44]. Rubika J, Felicita AS, Sivambiga V. Gonial angle as an indicator for the prediction of growth pattern. World J Dent. 2015;6(3):161-3.

[45]. Samantha C, Sundari S, Chandrasekhar S, Sivamurty G, Dinesh S. Comparative Evaluation of Two Bis-GMA Based Orthodontic Bonding Adhesives A Randomized Clinical Trial. J Clin Diagn Res. 2017 Apr;11(4):ZC40ZC44. Pubmed PMID: 28571259

[46]. Samuel SR. Can 5-year-olds sensibly self-report the impact of developmental enamel defects on their quality of life? Int J Paediatr Dent. 2021 
Mar;31(2):285-286. Pubmed PMID: 32416620.

[47]. Samuel SR, Acharya S, Rao JC. School Interventions-based Prevention of Early-Childhood Caries among 3-5-year-old children from very low socioeconomic status: Two-year randomized trial. J Public Health Dent. 2020 Jan;80(1):51-60. Pubmed PMID: 31710096.

[48]. Sitharthan R, Sundarabalan CK, Devabalaji KR, Yuvaraj T, Mohamed Imran A. Automated power management strategy for wind power generation system using pitch angle controller. Measurement and Control. 2019 Mar;52(3-4):169-82.

[49]. Sivamurthy G, Sundari S. Stress distribution patterns at mini-implant site during retraction and intrusion--a three-dimensional finite element study. Prog Orthod. 2016;17:4. Pubmed PMID: 26780464.

[50]. Sridharan G, Ramani P, Patankar S, Vijayaraghavan R. Evaluation of salivary metabolomics in oral leukoplakia and oral squamous cell carcinoma. J Oral Pathol Med. 2019 Apr;48(4):299-306. Pubmed PMID: 30714209.

[51]. Sukniyom P, Viteporn S. Pharyngeal Airway Changes Following Extraction versus Non-extraction Treatments of Class II Division 1 Growing Patients. Int J Oral Dent Health 2019;5:094.
[52]. Vijayashree Priyadharsini J. In silico validation of the non-antibiotic drugs acetaminophen and ibuprofen as antibacterial agents against red complex pathogens. J Periodontol. 2019 Dec;90(12):1441-1448. Pubmed PMID: 31257588.

[53]. Vikram NR, Prabhakar R, Kumar SA, Karthikeyan MK, Saravanan R. Ball Headed Mini Implant. J Clin Diagn Res. 2017 Jan;11(1):ZL02-ZL03. Pubmed PMID: 28274084.

[54]. Viswanath A, Ramamurthy J, Dinesh SP, Srinivas A. Obstructive sleep apnea: awakening the hidden truth. Niger J Clin Pract. 2015 Jan-Feb;18(1):1-7. Pubmed PMID: 25511335.

[55]. Wu F, Zhu J, Li G, Wang J, Veeraraghavan VP, Krishna Mohan S, Zhang Q. Biologically synthesized green gold nanoparticles from Siberian ginseng induce growth-inhibitory effect on melanoma cells (B16). Artif Cells Nanomed Biotechnol. 2019 Dec;47(1):3297-3305. Pubmed PMID: 31379212.

[56]. Yoo E, Murakami S, Takada K, Fuchihata H, Sakuda M. Tongue volume in human female adults with mandibular prognathism. J Dent Res. 1996 Dec;75(12):1957-62. Pubmed PMID: 9033450. 